\title{
Assisted death gaining acceptance in US
}

\author{
Cite as: CMAJ 2017 January 23;189:E123. doi: 10.1503/cmaj.109-5366
}

$\mathbf{T}$ he District of Columbia has become the latest jurisdiction in the United States to pass a bill to allow patients with terminal illnesses to end their lives with physician assistance. The district follows Colorado, which passed a right-to-die law on Nov. 8. Both measures permit assisted death to anyone over 18 who is terminally ill and estimated to have less than six months to live. Patients must be considered competent to make the decision and have to voluntarily ask for the service.

"The clear success of the Colorado law is part of our movement's step-by-step across the US to get intelligent, democratic laws on the right to choose to die in place," Derek Humphry, author of "Final Exit" and founder of the Hemlock Society USA, a right-to-die advocacy group (now part of the organization Compassion \& Choices), said in an email.

Opponents of physician-assisted death lament the new laws, fearing they will only lead to poor outcomes for certain vulnerable members of society.

"We worry for the residents of Colorado and Washington, DC, because assisted-suicide laws inevitably take the lives of innocent people through misdiagnosis and elder abuse," John Kelly, a regional director (New England) for the disability-rights group Not Dead Yet. "Given that insurers routinely value their bottom lines over patient treatment, and the health care system devalues the lives of disabled people, these laws reduce rather than expand choice."

The Colorado End of Life Options Act (Proposition 106) was opposed by many in the state. The editorial board of The Denver Post said the measure lacked proper safeguards, and recommended rejecting it "because we fear the cultural, legal and medical shift that it would create." The group Coloradans Against Assisted Suicide claimed that right-to-

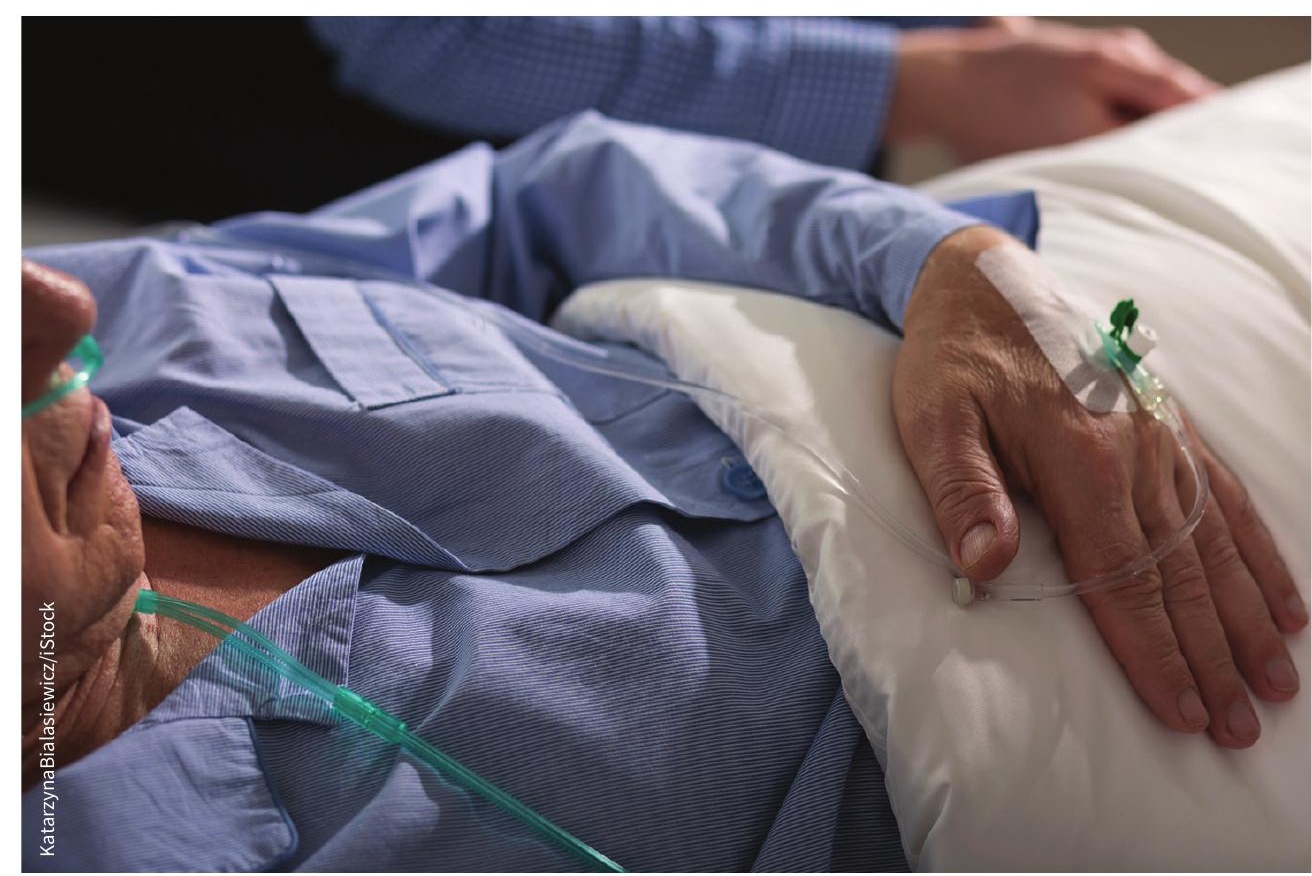

Residents of Colorado and the District of Columbia estimated to have less than six months to live to have access to assisted dying.

die legislation "leads people to give up on treatment and lose good years of their lives." Another group, No Prop 106, suggested the new law would put too much power in the hands of physicians, who sometimes make mistakes, to determine who has six months to live and is therefore eligible for assisted dying.

"Rarely do voters get to vote on ballot issues about life and death. We appreciate the support of so many Coloradans who reject a culture of compromise on suicide," Peggi O'Keefe, spokesperson for No Prop 106, said in an email. "We hope that the state legislature, as it has on two prior occasions, recognizes the flaws embedded in Proposition 106 and takes appropriate steps to correct them."

Five other states, in addition to Colorado and the District of Columbia, have already passed right-to-die legislation: Oregon, California, Vermont, Washington and Montana. Oregon's Death with Dig- nity Act came into effect nearly two decades ago, on Oct. 27, 1997. In California, the End of Life Option Act has been law since June 9 of this year. There are no federal laws on assisted death in the US.

"We are looking in the new year to get similar choice laws passed in New Jersey, New York and Connecticut," said Humphry. "This is an idea whose time has come."

Meanwhile, in some other countries, efforts to pass legislation for assisted dying have not been as successful as in the US. On Nov. 17, South Australia Parliament rejected the Death with Dignity bill by a single vote. The bill has appeared before parliament 15 times. A health committee in New Zealand is holding an inquiry into assisted dying, but the country's prime minister said the government wouldn't be introducing legislation.

Roger Collier, CMAJ 